\title{
Implementasi Metode Role Playing Pada Pembelajaran Tematik di Madrasah Ibtidaiyah Darul Ulum Sukorambi Jember Tahun Pelajaran 2018/2019
}

\author{
Ilmanuddin \\ MI Nurul Islam, Klakah Lumajang \\ Ilmanuddin60@gmail.com \\ Robby Sadha Siregar \\ Pengawas MI Mayang Jember \\ robbyrofarafi@gmail.com
}

\begin{abstract}
Abstrak
Kegiatan belajar mengajar siswa disekolah yang berpusat pada guru mengakibatkan siswa hanya menerima mata pelajaran secara pasif pembelajaran yang seperti ini mengakibatkan siswa kurang berminat dalam mengikuti pembelajaran tematik,proses pembelajaran yaitu kurang maksimal pelaksanaan proses pembelajaran yang diterapkan sehingga peserta didik kurang menarik dengan pembelajaran dan metode yang sebelumnya, Sehingga berpengaruh kepada pemahaman siswa. Fokus dalam penelitian ini adalah: 1) Bagaimana Perencanaan metode Rol Playing pada pembelajaran tematik di Madrasah IbidaiyahDarul Ulum Sukorambi Jember tahun pelajaran 2018/2019? 2) Bagaimana Pelaksanaan metode Rol Playing pada pembelajaran tematik di Madrasah IbidaiyahDarul Ulum Sukorambi Jember tahun pelajaran 2018/2019? 3) Bagaimana evalusai metode Role Playing pada pembelajaran tematik di Madrasah Ibidaiyah Darul Ulum Sukorambi Jember tahun pelajaran 2018/2019? Hasil dari penelitian ini adalah: Perencanaan metode Role Playing pada pembelajaran tematik di kelas IV yaitu: dengan menyusun Program tahunan, program semester, silabus dan RPP(Rencana Pelaksanaan Pembelajaran) dan dikembangkan dalam RPP dengan menggunakan metode Role Playing sehingga setiap siswa dapat memahami materi yang telah dipelajarinya.
\end{abstract}

Kata Kunci: Implementasi; Pembelajaran Tematik 


\section{PENDAHULUAN}

Kegiatan belajar mengajar siswa disekolah yang berpusat pada guru mengakibatkan siswa hanya menerima mata pelajaran secara pasif pembelajaran yang seperti ini mengakibatkan siswa kurang berminat dalam mengikuti pembelajaran tematik. Sehingga berpengaruh kepada pemahaman siswa oleh karena itu, guru dituntut bisa mengelola kegiatan pembelajaran yang dapat mengaktifkan siswa dalam menerima pelajaran dengan menerapkan metodeRole Playing, metode yang semula yaitu hanya mendengarkan dan hanya terpaku kepada teks bacaan. Dan berganti dengan bermain peran, perubahan ini dimaksudkan untuk memperbaiki mutu pembelajaran dan proses hasil belajar. Salah satu permasalahan yang dihadapi dalam proses pembelajaran yaitu kurang maksimal pelaksanaan proses pembelajaran yang diterapkan sehingga peserta didik kurang menarik dengan pembelajaran dan metode yang sebelumnya. Mengingat pada kurikulum ini sebagai seorang pendidik harus mampu membawa peserta didik untuk selalu senang dan aktif sehingga peserta didik dapat mengikuti pembelajaran dengan baik dan sesuai dengan perkembangan yang berlaku dengan melihat proses pembelajaran yang telah dilakukan. Kondisi ini menimpa pada pembelajaran tematik. Guru belum sepenuhnya menggunakan pembelajaran aktif yang melibatkan siswa serta kurang dalam penggunaan strategi pendekatan atau pembelajarannya.

Pada pendidikan kurikulum terpadu (Tematik) yang disebut juga Kurikulum 2013 banyak sekali pembelajaran yang membutuhkan kreatifitas para pendidik untuk melaksanakan dan mendidik para peserta didik yang sedang belajar sehingga dalam hal ini sebagai pendidik harus mempunyai banyak metode dalam melakukan proses pembelajaran yang sedang berlangsung. Proses pembelajaran terjadi dalam maupun luar kelas akan tetapi yang paling banyak digunakan adalah pembelajaran didalam kelas sehingga pendidik dalam hal ini harus mempunyai banyak metode demi 
kelancaran dalam proses pembelajaran dan beberapa metode yang harus disiapkannya.

Pembelajaran dalam hal ini adalah proses bagaimana guru menyampaikan materi yang telah disusun dan dijelaskan kepada peserta didik sehingga peserta didik faham dan tahu apa yang disampaikan dan yang dimaksudkan oleh guru dalam penyampaian materi tersebut.Sehingga proses pembelajaran dapat berjalan sesuai dengan apa yang telah rencanakan oleh guru.

Metode bermain peran adalah metode pembelajaran yang didalamnya menampakkan adanya perilaku pura-pura dari siswa yang terlihat dan peniruan dari tokoh tokoh sejarah sedemikian rupa. ${ }^{1}$ Dalam bermain pembelajaran bermain peran siswa dihadapkan dalam berbagai masalah sehingga mereka menampilkan apa yang berkaitan dengan pembelajaran yang dipelajari.

Metode bermain peran atau adalah sejenis permainan gerak yang didalamnya ada tujuan, aturan dan edutaiment dalalam RP, siswa dikondisikan pada situasi tertentu di luar kelas, selain itu sering dimaksudkan sebagai salah satu bentuk aktivitas dimana membayangkan dirinya seolah-olah berada di luar kelas dan memainkan peran orang lain. ${ }^{2}$

Prosedur bermain peran terdiri dari Sembilan langkah yaitu :

a) Pemanasan (Warming Up)

b) Memilih partisipan

c) Menyiapkan pengamatan (Observer)

d) Menata panggung

e) Memainkan peran (Manggung)

f) Diskusi dan Evaluasi

g) Memainkan Peran Ulang

\footnotetext{
${ }^{1}$ Mulyono, Strategi Pembelajaran (Malang: UIN-Maliki, 2011), 44-45.

${ }^{2}$ Miftahul Huda, Model-Model Pengajaran dan Pembelajaran (Yogyakarta: Pustaka Pelajar, 2016), 209.
} 
h) Diskusi dan Evaluasi dua

i) Berbagi pengalaman dan kesimpulan. ${ }^{3}$

Dalam melaksanakan prosedur bermain peran dijelaskan bahwa sebelum melangkah kepada proses bermain peran, guru menjelaskan terlebih dahulu dari tiap pembagian peran yang telah dibagikan guru kepada siswa serta siswa dapat memahami sikap dari tokoh yang akan mereka perankan.

Proses bermain peran dapat memberikan contoh tentang perilaku manusia dan sebagai sarana bagi siswa yaitu:

a) Menggali perasaannya

b) Memperoleh inspirasi dan pemahamannya yang berpengaruh pada sikap

c) Mengembangkan keterampilan dan sikap dalam memecahkan masalah

d) Mendalami mata pelajaran dengan berbagai macam cara. ${ }^{4}$

Adapun langkah langkah yang perlu diperhatikan dalam melakukan pembelajaran bermain peran sebagai berikut:

a) Guru menyusun (menyiapkan) scenario yang akan ditampilkan

b) Guru menunjuk beberapa scenario dalam waktu beberapa hari sebelum pelaksaan kegiatan belajar mengajar.

c) Guru membentuk kelompok siswa masing-masing beranggotakan 5 orang.

d) Guru memberikan penjelasan kompetensi yang ingin dicapai

e) Guru memanggil para siswa yang ditunjuk untuk melakukan scenario yang telah dipersiapkan

f) Masing-masing siswa berada dalam kelompoknya dan mengamati scenario yang sedang diperagakan

g) Setelah selesai ditampilkan, masing-masing siswa diberikan lembar kerja untuk membahas/memberi penilaian atas masing-masing kelompok.

h) Masing-masing kelompok menyampaikan hasil kesimpulannya.

\footnotetext{
${ }^{3}$ Hamzah B. Uno, Model Pembelajaran, (Jakarta: PT Bumi Aksara, 2008), 26.

${ }^{4}$ Hamzah B. Uno, Model Pembelajaran, 33.
} 
i) Guru memberikan kesimpulan secara umum, kemudian melakukan evaluasi seperti biasanya dan setelah itu penutup. ${ }^{5}$

Rencana pelaksanaan pembelajaran yang ideal adalah RPP yang sesuai dengan kondisi dan lingkungan peserta didik, jadi guru mendapatkan kesempatan seluas-luasnya untuk dapat mengembangkan RPP sesuai dengan kondisi di lapangan yang berpedoman pada standar minimal.

Peraturan pemerintah nomor 32 tahun 2013 bab IV pasal 20 perencanaan proses pembelajaran meliputi silabus, dan rencana pelaksanaan pembelajaran yang memuat sekurang-kurangnya 5 komponen pokok. ${ }^{6}$

a. Tujuan Pembelajaran

b. Materi Ajar

c. Metode Pengajaran

d. Sumber Belajar

e. Penilaian hasil belajar.

Dalam pembelajaran guru dan siswa sering dihadapkan berbagai masalah baik yang berkaitan dengan pembelajaran maupun menyangkut hubungan sosial. Pemecahan masalah dapat dilakukan melalui berbagai cara, diskusi kelas, tanya jawab, antara guru dan siswa, penemuan dan inkuiri.

Pembelajaran terpadu sebuah konsep dapat dikatan sebagai pendekatan belajar mengajar yang melibatkan beberapa bidang studi untuk memberikan pengalaman yang bermakna kepada anak. Dikatakan bermakna karena anak dalam pembelajaran terpadu akan memahami konsep-konsep yang mereka pelajari melalui pengalaman langsung dan menghubungkannya dengan konsep lain yang sudah mereka pahami, kegiatan pembelajaran terpadu tersebut memadukan materi dari bebrapa mata pelajaran dalam satu tema. Dengan demikian, pelaksaan belajar mengajar dengan cara ini paling

\footnotetext{
${ }^{5}$ Miftahul Huda, Model-Model Pengajaran dan Pembelajaran, Isu-Isu Metodis, 209210.

${ }^{6}$ Sugeng Listyo Prabowo, Perencanaan Pembelajaran (Malang: UIN Maliki Press, 2010), 145-146.
} 
tidak dapat dilakukan dengan dua cara yakni, materi beberapa mata peajaran disajikan dalam tiap pertemuan dan setiap pertemuan hanya menyajikan satu jenis mata pelajaran. Pada cara kedua, keterpaduannya diikat dengan satu tema pemersatu. ${ }^{7}$

Pembelajaran tematik adalah pendekatan pembelajaran yang mengintegrasikan berbagai kompetensi dari berbagai mata pelajaran kedalam tema dengan proses pembelajaran yang bermakna yang dosesuaikan dengan perkembangan siswa, pembelajaran yang dilaksanakan berkaitan dengan pengalaman lingkungan siswa. Pada bagaian selanjutnya akan dikemukakan mengenai hal-hal yang berkaitan dengan pembelajaran tematik yang di sekolah dasar. ${ }^{8}$

Dalam menerapkan Metode bermain peran yang sangat diperlukan adalah melihat dari prosedur atau membuat langkah-langkah dengan membuat RPP (perencanaan pelaksanaan pembelajaran).Berikut kegiatan inti dari menerapkan metode role playing pada pembelajaran tematik.

\section{HASIL DAN PEMBAHASAN}

Dari hasil temuan yang telah disajikan oleh, berikut ini akan dibahas kaitannya dengan teori-trori yang dipaparkan oleh tokoh dengan temuan dilapangan, maka dilanjutkan dengan temuan yang didapat dari hasil lapangan seperti berikut:

\section{Perencanaan Metode Role Pada Pembelajaran Tematik di MI Darul}

\section{Ulum Kecamatan Sukorambi Jember Tahun Pelajaran 2018/2019}

Sebagaimana dengan hasil wawancara dan observasi dan diketahui bahwa perencanaan metode bermain peran pada pembelajaran Tematik di

\footnotetext{
${ }^{7}$ Abdul Majid, Strategi Pembelajaran (Bandung:Rosda karya), 119-120.

${ }^{8}$ Sa'dun Akbar dan Iffah Qurotul A, Implementasi Pembelajaran Tematik di Sekolah Dasar (Bandung: Rosda Karya. 2017), 17.
} 
MI Darul Ulum Sukorambi Jember. Perencanaan pembelajaran merupakan awal dari suatu kegiatan yang berlangsung dalam kegiatan belajar mengajar, tanpa adanya perencanaan tujuan pembelajaran tidak akan tercapai. Berdasarkan hasil temuan peneliti dapat diketahui bahwa perencanaan metode sebagai acuan dari proses pembelajaran pada tematik dalam membentuk karakter.

Hal tersebut sesuai dengan sesuai dengan pendapat denganpendapat yang dikembangkan oleh abdul majid sebagai berikut:

"Perencanaan adalah menentukan apa yang akan dilakukan. Perencanaan mengandung rangkaian-rangkaian putusan yang luas dan penjelasan-penjelasan dari tujuan, penentuan kebijakan, penentuan program, penentuan metode-metode dan prosedur tertentu dan penentuan kegiatan berdasarkan jadwal sehari-hari."

Berdasarkan pendapat tersebut bahwasanya perencanaan Metode bermain peran pada pembelajaran tematik merupakan keharusan yang harus dilakukan oleh guru guna mengatur kesesuaian jalannya proses belajar mengajar di dalam kelas dengan tujuan yang akan dicapai.

Ada hal yang paling penting dari perangkat pembelajaran yang didukung oleh Abdul Majid dari perencanaan pembelajaran tentang unsurunsur silabus yaitu:

“ a. Tujuan mata pelajaran yang akan diajarkan, b. Sasaran- sasaran mata pelajaran, c. Keterampilan yang diperlukan agar dapat menguasai mata pelajaran dengan baik.d.Urutan topik- topik yang diajarkan, e. aktivitas dan sumber-sumber belajar pendukung keberhasilan pengajaran.f. berbagai tehnik evaluasi yang digunakan." $" 10$

Berkenaan dengan dengan komponen silabus lebih rinci, bahwa silabus berisi uraian program yang mencamtumkan. ${ }^{11}$

\footnotetext{
${ }^{9}$ Abdul Majid, Perencanaan Pembelajaran Mengembangkan Standar Kompetensi Guru, (Bandung: PT. Remaja Rosdakarya, 2011), 15-16.

${ }^{10}$ Abdul Majid, Perencanaan pembelajaran Mengembangkan Standar Kompetensi Guru, 39-40.

${ }^{11}$ Ibid., 40
} 
"a. Bidang studi yang diajarkan, b. Tingkat sekolah atau madrasah, semester, c. Pengelompokkan kompetensi dasar, d. Materi pokok, e. Indikator, f. Strategi pembelajaran, g. Alokasi waktu, h. Bahan, alat dan media"

Selanjutnya adalah yang terakhir yaitu RPP yang di dukung oleh Sugeng Listyo Prabowo berkenaan dengan komponen Rencana Pelaksanaan Pembelajaran setidaknya ada 5 berikut ini :

“a. Tujuan Pembelajaran, b. Materi Ajar, c. Metode Pengajaran, d. Sumber Belajar, e. Penilaian hasil belajar.

Jadi, pada tahap ini perencanaan pembelajaran melalui metode bermain perantelah dipersiapkan seluruh perangkat pembelajran yang diperlukan dalam pembelajaran yaitu menyusun RPP, dengan beracuan silabus, menyusun instrument penilain dan membagikan peran sebelum pelaksanaan pembelajaran aka nada pembagian peran tiap siswa satu dengan yang lain berbedam sehingga siswa akan bersemangat dalam belajar. Perencanaan pembelajaran metode ini sangat penting sebelum melakukan pembelajaran harus dipersiapkan karena perencanaan sangat penting untuk dilakukan sebelum melaksanakan pembelajaran agar pembelajran bisa terarah dan guru juga mudah dalam melaksanakan pembelajaran.

\section{Pelaksanaan Metode Pada Pembelajaran Tematik Di MI Darul Ulum Sukorambi Jember Tahun Pelajaran 2018/2019}

Metode bermain peran adalah metode pembelajaran yang didalamnya menampakkan adanya perilaku pura-pura dari siswa yang terlihat dan peniruan dari tokoh tokoh sejarah sedemikian rupa. ${ }^{12}$

Model metode Role Playing yaitu guru menyiapkan scenario pembelajaran, menunjuk beberapa siswa untuk mempelajari scenario tersebut, pembentukan kelompok siswa, menunjuk siswamelakonkan

\footnotetext{
${ }^{12}$ Mulyono. Strategi Pembelajaran (Malang: Uin-maliki, 2011), 44-45.
} 
scenario yang telah dipelajarinyam kelompok siswa membahas peran yang dilakuakan oleh pelakon. ${ }^{13}$

Dalam metode ini kelompok yang membahas dan memerankan beberapa peran yang telah disiapkan oleh guru para siswa diminta agar memahami apa yang akan diperankan sehingga perlu didiskusikan dengan kelompok sehingga tercipta suasa yang cocok dengan tokoh yang akan diperankan.

Pelaksanaan pembelajaran metode bermain peran (Role playing) pada pembelajaran Tematik di MI Darul Ulum Sukorambi Jember memberikan kesempatan kepada siswa untuk lebih aktif saat pembelajaran berlangsung.

Adapun pelaksanaan metode bermain peran pada pembelajaran tematik di kelas IV MI Darul Ulum Sukorambi Jember telah sesuai dengan langkah-langkah metode Role Palaying.

Jadi, pada tahap perencanaan pembelajaran melalui metode bermain peran ini telah dipersiapkan seluruh perangkat pembelajaran yang diperlukan dengan beracuan pada silabus, menyusun instrumen penilaian, dan membagikan peran sebelum pelaksanaan pembelajaran akan ada pembagian peran tiap siswa satu dengan siswa yang lain, sehingga siswa akan semangat dalam belajar. Perencanaan pembelajaran ini telah sesuai dengan perencanaan pembelajaran yang harus dipersiapkan sebelum pelaksanaan karena perencanaan sangatlah penting sebelum melakukan pembelajaran agar pembelajaran sesuai dan terarah sehingga guru mudah dalam melaksanakan pembelajaran.

\footnotetext{
${ }^{13}$ Ida Zusnani. Pendidikan Kepribadian Siswa (Jakarta:Tugu Publisher, 2013), 45.
} 


\section{Evaluasi Metode Pada Pembelajaran Tematik Di MI Darul Ulum Sukorambi Jember Tahun Pelajaran 2018/2019}

Setelah merencanakan dan juga melakukan pelaksanaan pembelajaran tentu adanya evaluasi. Seorang guru mengevaluasi tentang penyesuaianyang sudah direncanakan oleh guru.

Tahap evaluasi metode pembelajaran bermain peran pada pembelajaran tematik di kelasn IV MI Darul Ulum Sukorambi Jember diantaranya :

a. Evalusi Proses

1) Guru sudah dapat menilai dari awal siswa pembagian peran, jika siswa gaduh atau bingung dengan peran yangakan diperankan dan juga saat praktek atau presentasi tidak bisa maka nilainya kurang bagus.

2) Guru meminta siswa mempresentasikan tiap kelompok jika sesuai dengan pembagiannya.

3) Guru memberikan penghargaan kepada siswayang presentasin yang paling bagus dan terlihat aktif dikelas.

b. Evaluasi hasil

Evaluasi hasil yang didapat dari hasil siswa menjawab soal yang telah dberikan atau dari ulangan harian, tugas dan lain-lain.

Temuan-temuan tersebut selaras dengan Moh. Sahlan dalam bukunya evalusi pembelajaran, yang menyatakan :

"Evalusai adalah penyediaan informasi yang dapat dijadikan sebagai bahan pertimbangan dalam pengambilan keputusan."

Secara umum evaluasi bertujuan untuk melihat sejauh mana suatu kegiatan tertentu dapat mencapai tujuan yang telah ditentukan, dengan digunakannya evaluasi hasil dan evaluasi proses sama halnya dengan menggunakan tehnik tes dan non-tes, yang menurut Moh. Sahlan tehnik tes adalah penilaian yang dilakukan dengan tes, baik itu tes tulis ataupun wawancara. Sedangkan tehnik non-tes adalah penilaian yang dilakukan 
tanpa melalui tes, biasanya digunakan untuk menilai karakteristik dari siswa, bisa melalui observasi, skala sikap, angket dan wawancara. ${ }^{14}$

Menurut Hamzah bermain peran dapat memberikan contoh tentang perilaku manusia dan sebagai sarana bagi siswa dan sangat penting yaitu: Menggali perasaannya, Memperoleh inspirasi dan pemahamannya yang berpengaruh pada sikap, Mengembangkan keterampilan dan sikap dalam memecahkan masalah, Mendalami mata pelajaran dengan berbagai macam cara.

Sehingga dalam pembelajaran juga tidak harus objek dari manusia akan tetapi bermain peran juga dilakukan untuk semua makhluk hidup sehingga beberapa yang akan dilakuakan objek dan bermain peran. Dengan demikian siswa dapat memahami karakter dan kondisi yang akan dijadikan objek untuk menirukan beberapa tokoh dan semacamnya.

Jadi implementasi metode melalui dari awal, perencanaan, pelaksanaan dan evaluasi. Evaluasi proses dan evaluasi hasil yang digunakan dalam penerapan metode pada Pembelajaran Tematik di kelas IV di Madrasah Ibtidaiyah Sukorambi Jember, siswa lebih memahami dan mengerti dari proses sehingga dapat menanamkan jiwa nilai-nilai positif yang bisa diambil dari tema denagn jenis-jenis pekerjaan yang diperankan siswa. Sedangkan evaluasi hasil dapat dilihat dari nilai tugas ulangan harian dan ujian semester.

\footnotetext{
${ }^{14}$ Moh. Sahlan, Evaluasi Pembelajaran. 107-177
} 


\section{KESIMPULAN}

Setelah dilakukan analisi data yang diperoleh tentang penerapan Metode dalam meningkatkan hasil belajar siswa pada pelajaran tematik di Madrasah Ibtidaiyah Darul Ulum Sukorambi Jember tahun pelajaran 2018/2019. Maka diperoleh kesimpulan sebagai berikut: 1) Perencanaan metode padapembelajaran tematik di kelas IV yaitu: dengan menyusun Prota, Promes, Silabus dan RPP. Akan tetapi dikembangkan dalam RPP dengan menggunakan metode sehingga setiap siswa dapat memahami materi yang telah dipelajarinya. 2) Pelaksanaan metode pada pembelajaran tematik kelas IV pada pembelajaran tematik di kelas IV yaitu: guru memberikan skenario pada tiap kelompok kepada semua siswa, guru membagi tiap kelompok yang terdiri dari 5 anggota siswa, guru membagikan peran tiap kelompok yang berbeda tiap siswa, guru memberikan waktu latihan sebelum pelaksanaan metode bermain peran, guru memilih secara acak tiap kelompok untuk mempraktekkan didepan kelas secara bergantian, kelompok yang mempraktekkan didepan kelas dan audiens memperhatikan, mengamati dan menilai kelompok temannya sendiri yang mempraktekkan di depan kelas, guru memberikan kesimpulan secara umum. 3) Evaluasi metode pada pembelajaran tematik di kelas IV yaitu: evaluasi proses dan evaluasi hasil, siswa lebih memahami dan mengerti dari proses dapat menanamkan karakter siswa siswa dalam kehidupan sehari-hari, menumbuhkan sikap menghargai dan tolong menolong, serta dapat menerima segala apa yang telah dijalaninya. Sedangkan evaluasi hasil bisa dilihat dari nilai tugas, ulangan dan ujian semester. 


\section{DAFTAR PUSTAKA}

A, Yanuar. Rahasia Menjadi Guru Faforit, Yogyakarta: Diva Press, 2015.

Akbar, Sa'dun dan Iffah Qurotul A. Implementasi Pembelajaran Tematik di Sekolah Dasar, Bandung: Rosda Karya, 2017.

Huda, Miftahul. Model-model Pengajaran dan Pembelajaran, Yogyakarta. Pustaka Pelajar, 2016.

Kurniasih, Imas. Ragam Pengembangan Model Pembelajaran untuk Meningkatkan Profesionalitas guru, Bandung: Kata Pena, 2017.

Lefudin. Belajar dan Pembelajaran, Yogyakarta: CV. Budi Utama. 2017.

Majid, Abdul. Strategi Pembelajaran, Bandung: Rosda Karya, 2013.

Moelong, Lexi. Metodologi Penelitian Kualitatif. Bandung: Rosdakarya, 2010 .

Mulyasa. Pengembangan Implementasi kurikulum 2013, Bandung: PT. Remaja Rosda Karya, 2014.

Mulyono. Strategi Pembelajaran, Malang: Uin-maliki, 2011.

Musfiqon. Panduan Lengkap Metodologi Penelitian Pendidikan, Jakarta: Prestasi Pustakarya, 2012.

Ngalimun, M, Purwanto. Prinsip-prinsip dan Teknik Evaluasi Pengajaran, Bandung: Rosda Karya, 2010.

Noor, Juliansyah. Metodologi Penelitian, Jakarta: Prenada Media Group, 2014.

Purwanto. Evaluasi Hasil Belajar, Yogyakarta: Pustaka Pelajar, 2011.

Rodliyah, St. Pendidikan dan Ilmu Pendidikan, Jember: STAIN Jember Press, 2013. 
Rukajad, Ajad. Manajemen Pembelajaran. Yogyakarta: CV Budi Utama, 2018.

Sahlan, Moh. Evaluasi pembelajaran. Jember: Stain Press, 2013.

Sudjana, Nana. Penilaian hasil belajar mengajar. Bandung: Rosdakarya, 2002.

Sugiyono. Kuantitatif \& Kualitatif. Bandung: Alfabeta, 2013.

Sugiyono. Metode Penelitian Kuantitatif, Kualitatif, dan R\&D. Bandung: Alfabeta, 2014.

Suparlan, Suhartono. Filsafat Pendidikan. Jogjakarta: Ar-Ruzz Media Group, 2009.

Suprijini, Agus. Model-model Pembelajaran Emansipatoris. Yogyakarta: Pustaka Pelajar, 2016.

Susanto, Ahmad. Teori Belajar dan Pembelajaran di Sekolah Dasar. Jakarta: Prenada Group, 2013.

Tim Penyusun. Pedoman Penulisan Karya Ilmiah. Jember: IAIN Jember Press, 2017.

Uno, Hamzah B. Model Pembelajaran. Jakarta: PT Bumi Aksara, 2008.

Usman, Nurdin. Konteks Implementasi Berbasis Kurikulum, Jakarta: PT raja Grafindo persada, 2002.

Zusnani, Ida. Pendidikan Kepribadian Siswa. Jakarta: Tugu Publisher, 2013. 